\title{
Review \\ Imaging in breast cancer: Single-photon computed tomography and positron-emission tomography
}

\author{
François Bénard and Éric Turcotte
}

Metabolic and Functional Imaging Center, Clinical Research Center, Centre hospitalier universitaire de Sherbrooke, Fleurimont, QC, Canada

Corresponding author: François Bénard, francois.benard@usherbrooke.ca

Published: 12 May 2005

This article is online at http://breast-cancer-research.com/content/7/4/153

(c) 2005 BioMed Central Ltd
Breast Cancer Research 2005, 7:153-162 (DOI 10.1186/bcr1201)

invasive sentinel node biopsy may not always detect axillary involvement because the sentinel nodes can be bypassed in 3 to $7 \%$ of cases [2-5]. Nodal metastases can also occur in internal mammary or mediastinal nodal groups, which are usually not sampled in conventional surgical staging. Multiple imaging studies are often prescribed to exclude the presence of bone, liver and lung metastases.

Despite some progress arising from increased public awareness and screening programs that have tended to improve the stage at which breast cancers are detected, the rate of recurrence remains significant. In 2005, the death : case ratio for breast cancer in Canada has been estimated to be 0.24 [6]. Efficient imaging techniques are warranted for the accurate assessment of recurrent and metastatic disease. The preferred treatment will often be proposed by oncologists on the basis of the integration of several factors, such as the tumor pathologic grade, the age of the patients, the presence or absence of estrogen receptors (ERs) and the site of recurrence [7-9]. To validate whether the treatments are appropriate, the disease burden often needs to be assessed before and after treatment.

Among the various imaging techniques used to assess primary or recurrent breast cancer, radionuclide imaging techniques such as planar scintigraphy, single-photonemission computed tomography (SPECT) and positronemission tomography (PET) can provide an accurate assessment of the presence and extent of disease as well as unique information about tumor biological characteristics such as the rate of proliferation and metabolic activity.

\section{Planar scintigraphy, SPECT and PET}

Planar scintigraphy has been used in nuclear medicine for over 40 years and is widely available across hospitals dissection, a diagnostic surgical procedure that can significantly impair the quality of life of many women. The less

${ }^{18} \mathrm{~F}-\mathrm{FDG}=\left[{ }^{18} \mathrm{~F}\right]$ fluorodeoxyglucose; ${ }^{18} \mathrm{~F}-\mathrm{FLT}=3^{\prime}$-deoxy-3'-[18 $\left.\mathrm{F}\right]$ fluorothymidine; ${ }^{18} \mathrm{~F}-\mathrm{FES}=16 \alpha$-[18 $\left.\mathrm{F}\right]$ fluoro-173-estradiol; $99 \mathrm{mTc}-\mathrm{MIBI}=99 \mathrm{mTC}-$ methoxyisobutylisonitrile ( ${ }^{99 \mathrm{mT} c-s e s t a m i b i) ; ~}{ }^{99 \mathrm{mTc}}=$ technetium-99m; $\sigma_{1}, \sigma_{2}=$ sigma receptors; CT = computed tomography; ER $=$ estrogen receptor; FWHM = full width at half maximum; MIVE $=17 \alpha-[123]]$ iodovinyl-11 $\beta$-methoxyestradiol; $\mathrm{MRI}=$ magnetic resonance imaging; $\mathrm{PEM}=$ positron-emission mammography; PET = positron-emission tomography; PPV = positive predictive value; SMM = scintimammography; SPECT = single-photon-emission computed tomography. 
worldwide. This technique consists of injecting a radiopharmaceutical, typically labeled with technetium-99m (99mTc), into a patient, followed by planar imaging with a conventional gamma camera. SPECT images are threedimensional reconstructions of rotating planar images acquired over a $180^{\circ}$ or $360^{\circ}$ arc around the patient. Typical radiopharmaceuticals used in planar imaging and SPECT for breast cancer imaging include 99mTc-diphosphonates (for bone scans), [201Tl]thallium chloride, ${ }^{99 m T c}$-tetrofosmin and 99mTc-methoxyisobutylisonitrile (99mTc-MIBI; ${ }^{99 m T c}$-sestamibi). PET is an imaging technique that permits the detection of annihilation photons produced by the disintegration of positron-emitting radioisotopes. Typical radioisotopes used in PET imaging are oxygen-15, nitrogen-13, carbon-11 and fluorine-18. In the past few years, the use of PET imaging in oncology has grown rapidly, with the development of several ligands for cancer detection such as [ $\left.{ }^{18} \mathrm{~F}\right]$ fluorodeoxyglucose (18 F-FDG) [10], 3'-deoxy-3'-[18F]fluorothymidine (18 F-FLT) [11] and $16 \alpha-[18 \mathrm{~F}]$ fluoro-17 $\beta$-estradiol (18 F-FES) [12]. PET imaging requires expensive equipment and a supply of shortlived isotopes. ${ }^{18} \mathrm{~F}-\mathrm{FDG}$, the most commonly used radiopharmaceutical, is now widely available in most urban centers. There has been considerable progress in PET equipment technology over the past few years. New systems now commercialized offer an integrated computed tomography (CT) scanner for simultaneous PET and CT (PET/CT) imaging to combine the sensitivity of PET imaging with the anatomical localization capabilities of CT. Positron-emission mammography (PEM) devices are dedicated high-resolution instruments that may have value in detecting primary breast cancer.

\section{Scintimammography Primary breast cancer}

Over the last several years, many clinical studies in the medical literature have shown that $99 \mathrm{mTc}-\mathrm{MIBI}$, normally used for myocardial perfusion imaging, concentrates in breast cancers (Fig. 1) [13]. This uptake is due to an increase in blood flow, number of mitochondria and cancer cell membrane hyperpolarization in the tumor and as a function of the expression of the multidrug resistance gene [14-17]. Since FDA approval, $99 \mathrm{~m}$ Tc-MIBI scintimammography (SMM) has been used clinically to evaluate patients with a palpable breast abnormality when mammography is negative or indeterminate. For optimal imaging, patients are placed in prone position over a special table with a lateral cut-off or a foam cushion with the breast hanging freely. The breast is not compressed as part of the procedure. In a recent metaanalysis summarizing studies from 5,340 patients, the overall aggregated sensitivity and specificity of SMM in detecting a palpable primary breast cancer were, respectively, $85.2 \%$ and $86.6 \%$ [13]. For non-palpable breast lesions, the sensitivity and specificity of SMM were $66.8 \%$ and $86.9 \%$, respectively.

SMM and ${ }^{18}$ F-FDG-PET have similar sensitivities and specificities in detecting primary breast cancers [18]. In

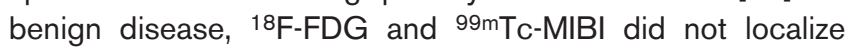

Figure 1

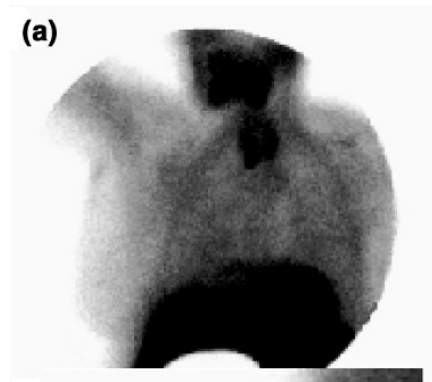

(b)
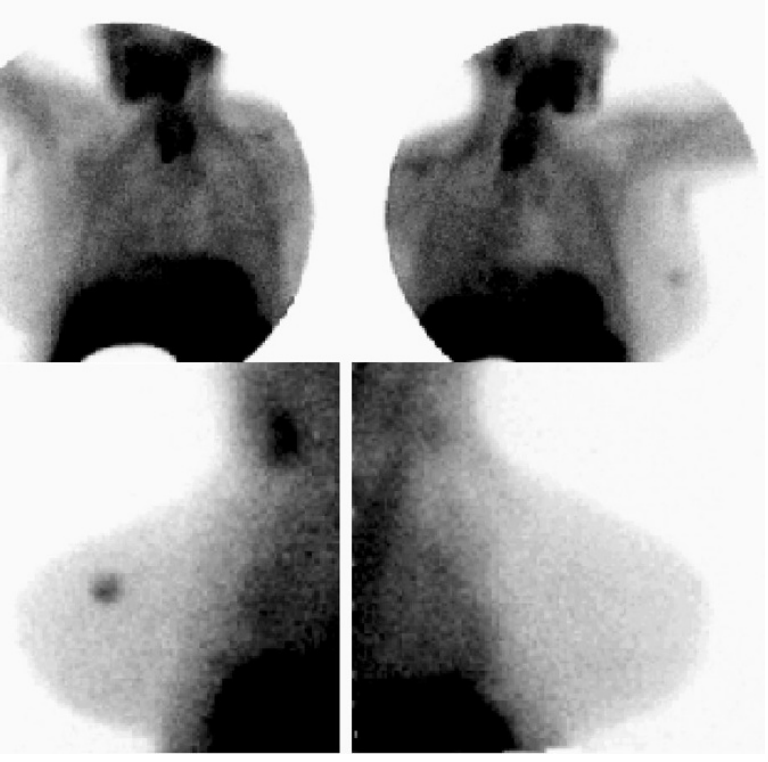

99mTc-methoxyisobutylisonitrile mammoscintigraphy showing a typical case of breast cancer in the external upper quadrant of the left breast. Panel (a) shows the anterior planar images. Lateral images obtained in the prone position (b) are obtained to improve the detection of smaller breast lesions

fibrocystic lesions, but could falsely identify fibroadenomas as cancer. Globally, the diagnostic accuracies of planar SMM and SPECT SMM [19] were equivalent to that of ${ }^{18} \mathrm{~F}-\mathrm{FDG}$ PET for the detection of primary breast cancer. For the detection of lymph node metastases of the axilla, ${ }^{18} \mathrm{~F}-\mathrm{FDG}$ was more sensitive than planar SMM (sensitivity 36 to $84 \%$, specificity 86 to $100 \%$ [19-21]) and SPECT SMM, in which sensitivity in some studies seemed to be superior to that of planar imaging (sensitivity 37.5 to $84.2 \%$, specificity $91 \%$ $[19,22])$. Statistically, SPECT-SMM did not significantly improve the diagnostic accuracy over planar SMM. Neither 18F-FDG-PET, SPECT SMM nor planar SMM are sufficiently sensitive to rule out axillary lymph node metastases. For that purpose, axillary dissection or sentinel lymph node biopsy remain the best available techniques.

In a more recent study, Cwikla and colleagues cautioned that SMM should be interpreted in combination with mammography to produce more accurate results than either modality alone (combined results: sensitivity 92\%, specificity $80 \%$, positive predictive value $89 \%$ and negative predictive value $86 \%$; SMM: $87 \%, 65 \%, 81 \%$ and $75 \%$; mammography: $69 \%, 72 \%, 81 \%$ and 57\%, respectively) [23]. $99 \mathrm{mTc}-\mathrm{MIBI}$ SMM could not be used for the routine evaluation of all microcalcifications detected by mammography (sensitivity $58 \%$, specificity $81 \%$ ); SMM was more often positive in high-grade than in low-grade or intermediate-grade ductal carcinoma in situ [24]. SMM was also proposed as a complementary study 
for evaluating younger patients (less than 50 years old) with dense breasts, even when mammography was negative, because $60 \%$ of those cases could be genuinely positive under SMM [25]. SMM should not be used to exclude malignancy whenever histopathological clarification of a suspicious lesion is necessary [26]. When SMM is positive, a biopsy is necessary because a high proportion of these lesions will prove to be cancerous. Although fewer biopsies may be required, the percentage of positive biopsies should increase, leading to a more cost-effective approach to core needle biopsy.

SMM has also been used to assess tumor response to treatment. Mankoff and colleagues reported that $99 \mathrm{mTC}-\mathrm{MIBI}$ imaging could accurately assess the response to neoadjuvant chemotherapy in patients with locally advanced breast carcinoma [27]. The assessment of response to treatment (5fluorouracil, epirubicin and cyclophosphamide) was accurate only after completion of neoadjuvant chemotherapy. SMM was unable to predict the response after one cycle [28]. A positive $99 \mathrm{mTc}-\mathrm{MIBI}$ scan was highly predictive of the presence of significant residual disease on completion of chemotherapy [29]. However, a negative 99mTc-MIBI scan could not rule out the presence of considerable residual tumor. Whereas ultrasound and clinical assessment underestimated the response to chemotherapy, $99 \mathrm{mTC}-\mathrm{MIBI}$ imaging tended to overestimate the response [29]. High primary breast tumor $99 \mathrm{mTc}-\mathrm{MIBI}$ uptake after neoadjuvant chemotherapy predicted poor survival, suggesting that serial $99 \mathrm{mTC}-\mathrm{MIBI}$ imaging could provide a useful quantitative surrogate endpoint for neoadjuvant chemotherapy [30]. Finally, ${ }^{99 m T c-M I B I ~ S M M ~ w a s ~ u s e f u l ~ t o ~ d e t e r m i n e ~ P-g l y c o-~}$ protein and multidrug resistance-related protein expression in patients with breast cancers, and therefore could predict resistance to further chemotherapy [31].

\section{Locally recurrent breast cancer}

The detection of recurrent breast cancer by mammography is a challenging task because architectural changes, mainly fibrosis and scarring secondary to surgery and radiotherapy, cause difficulties in the interpretation of mammograms. In a prospective trial [32] performed in the year 2000 to assess the accuracy of $99 \mathrm{mTc}-\mathrm{MIBI}$ SMM in women with suspected recurrent breast cancer in the breast and/or locoregional tissues, the sensitivity of SMM was $78 \%$ in detecting recurrent disease, compared with $42 \%$ for mammography. In addition, SMM identified $63 \%$ of axillary lymph nodes with recurrent tumor. SMM is believed to be more accurate than mammography in identifying recurrent disease in the breast and can identify locoregional recurrence outside the breast.

\section{PET imaging with ${ }^{18}$ F-FDG}

PET imaging can capitalize on the excessive utilization of glucose by malignant cells by measuring the uptake of ${ }^{18} \mathrm{~F}$ FDG [33], a derivative of glucose. ${ }^{18} \mathrm{~F}-\mathrm{FDG}$ is transported across the cell membrane of malignant cells by the glucose transporters Glut-1 and Glut-3 and then phosphorylated by hexokinase [34]. 18F-FDG-6-phosphate is trapped in tumor cells in proportion to the utilization of glucose [35]. Hypoxia and inflammation contribute in part to the increased retention of ${ }^{18} \mathrm{~F}-\mathrm{FDG}$ in tumor tissues [36-38]. Avril and colleagues found weak but significant correlations between 18F-FDG uptake and the histological subtype of breast cancers, tumor cell density, microscopic vascular invasion, the expression of Glut-1, the proliferation rate and the number of lymphocytes [39]. Crippa and colleagues noted that lobular carcinomas had a low avidity for ${ }^{18} \mathrm{~F}-\mathrm{FDG}$, and that ${ }^{18} \mathrm{~F}-\mathrm{FDG}$ uptake had no correlation with the thymidine labeling index or the presence of hormone receptors [40].

\section{Primary breast cancer}

Many groups have studied the role of ${ }^{18} \mathrm{~F}-\mathrm{FDG}-\mathrm{PET}$ in the evaluation of suspicious breast lesions, with sensitivity values ranging between 80 and $90 \%$, and specificity values between 71 and 95\% [41-47]. In a series of 117 patients with primary breast cancer, Schirrmeister and colleagues showed that PET was twice as sensitive as the combination of mammography and ultrasound in detecting multifocal tumor involvement of the breasts and could upstage the disease in some cases [48]. However, like SMM, ${ }^{18} \mathrm{~F}-\mathrm{FDG}$ is limited by a lower sensitivity in detecting some breast tumors because of their small size, metabolic activity, histological subtype, microscopic tumor growth pattern and proliferation [39]. No correlation was demonstrated between primary tumor size, lymph node status, percentage of tumor cells, presence of inflammatory cells, histopathologic grade, steroid receptor status, expression of glucose receptors Glut-1 and the uptake of FDG by the primary tumor [39]. The value of 18F-FDG-PET was compared with dynamic contrastenhanced magnetic resonance imaging (MRI) in a small study with a limited number of subjects [49]. No significant differences could be demonstrated between PET and MRI. Although ${ }^{18} \mathrm{~F}-\mathrm{FDG}-\mathrm{PET}$ can be a useful adjunct to mammography in characterizing primary breast tumors, this technique is limited by a low sensitivity to detect small tumors and lobular carcinomas [39]. The lack of evidence to demonstrate clear advantages over other complementary techniques and the high cost of PET imaging has limited the use of this tool in the routine diagnosis of primary breast cancer.

PEM has been introduced as a lower-cost, dedicated alternative to PET with a higher spatial resolution designed to detect small primary breast cancers. PEM typically uses two opposite coincident detector heads placed on each side of the breast. These positron detectors can be mounted on a mammographic gantry with or without a stereotactic biopsy unit to permit simultaneous or sequential analysis of the breast. The first clinical PEM case study was published in 1996 and demonstrated visualization of primary breast cancer in vivo within an imaging time of $4 \mathrm{~min}$ [50]. The original system had a spatial resolution of $2.8 \mathrm{~mm}$ full width at half maximum (FWHM), required a tumor:background ratio 
uptake of $6: 1$ to obtain an image of contrast 1.86:1, and was incapable of imaging lesions within $2 \mathrm{~cm}$ of the chest wall because of limitations in the field of view [50]. In a study of 14 patients [51] (10 malignant and 6 benign lesions) using a $10 \%$ asymmetry of breast uptake or intense focal uptake as criteria of malignancy, PEM had a sensitivity of $80 \%$ and specificity of $100 \%$. In a recent series [52] among 18 breast lesions (7 malignant and 11 benign), using a threshold of greater than 2.5:1 lesion: background ratio, PEM showed a sensitivity of $86 \%$, a specificity of $91 \%$, and an accuracy of $89 \%$. The only false negative originated from an invasive lobular carcinoma. Since 2000 PEM scanner technology has evolved rapidly, with larger fields of view $(15 \mathrm{~cm} \times 20 \mathrm{~cm})$ [53] as well as improved spatial resolution and count sensitivity. In a study conducted with a new-generation PEM scanner and in which a majority of lesions measured $2.5 \mathrm{~cm}$ and less, Rosen and colleagues reported a sensitivity of $86 \%$ [53]. Two false positives were identified in this study as fat necrosis. Two ductal adenocarcinomas and one ductal carcinoma in situ between 0.8 and $2.8 \mathrm{~cm}$ were not visualized. PEM scanners recently reached a spatial resolution of $1.5 \mathrm{~mm}$ FWHM [54]. This might improve the sensitivity of ${ }^{18} \mathrm{~F}-\mathrm{FDG}$ in detecting very small breast cancers. However, low uptake of $18 \mathrm{~F}-\mathrm{FDG}$ by some breast cancers and abnormal uptake by some inflammatory lesions are unlikely to be resolved with this method.

\section{Axillary metastases}

Many articles published between 1996 and 1997 suggested that ${ }^{18} \mathrm{~F}-\mathrm{FDG}$-PET could be accurate in detecting axillary nodal metastases, reaching sensitivity values in the range 79 to $100 \%$ and specificity values ranging from 66 to $100 \%[44,55-$ 57]. A large single-center study by Greco and colleagues, published in 2001, also suggested that PET was highly accurate in staging the axilla, with an overall accuracy of $90 \%$ [58]. Several recent studies have somewhat dampened the initial enthusiasm for using PET for this purpose: for example, studies by Fehr and colleagues [59] and Barranger and colleagues [60] conducted in clinically node-negative patients both found a sensitivity of only $20 \%$ for $18 \mathrm{~F}$-FDG-PET compared with sentinel-node biopsy. A recent prospective multicenter study conducted on 360 women with newly diagnosed invasive breast cancer reported values of $61 \%$, $80 \%, 62 \%$ and $79 \%$ for sensitivity, specificity and positive and negative predictive values, respectively [61]. ${ }^{18} \mathrm{~F}-\mathrm{FDG}-\mathrm{PET}$ was less sensitive in detecting axillary metastases from lobular carcinoma (sensitivity 25\%) than ductal carcinoma (sensitivity $66 \%$ ). PET was unable to detect axillary metastases in several cases with a limited number of small involved nodes. Lovrics and colleagues published a prospective study in 98 patients with clinical stage I or II breast cancer, and found a sensitivity of $40 \%$ with a specificity of $97 \%$ [62]. Given the impact of the axillary status on the decision to administer adjuvant chemotherapy, the current data suggest that the predictive accuracy of ${ }^{18} \mathrm{~F}-\mathrm{FDG}$-PET is insufficient to recommend this
Figure 2 (a)

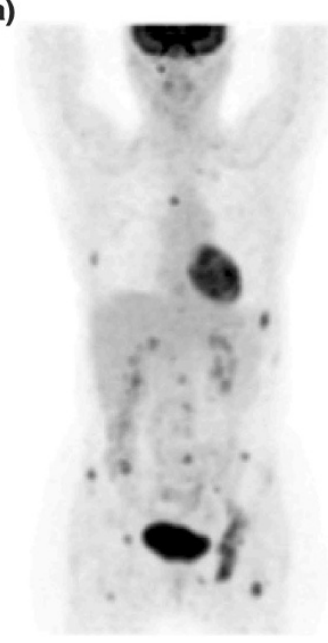

(b)

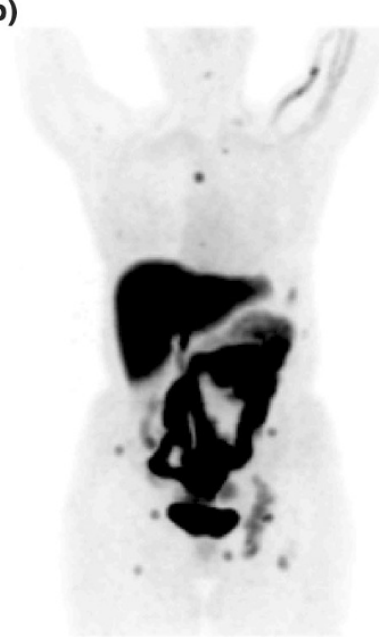

[18F]Fluorodeoxyglucose (18F-FDG) (a) and $16 \alpha$-[18F]fluoro-17 $\beta$ estradiol (18F-FES) (b) positron-emission tomography (PET) studies obtained in a patient with newly diagnosed metastatic recurrent breast cancer in the bones. The bone metastases are readily seen in both studies. Whereas ${ }^{18} \mathrm{~F}$-FDG-PET images provide information about the metabolic activity of the metastases, ${ }^{18} \mathrm{~F}$-FES images can demonstrate that the recurrent lesions still express high levels of estrogen receptors.

\section{Recurrent and metastatic breast cancer}

With clinically suspected recurrences, in addition to a complete history and physical examination, the commonly used restaging tools are radionuclide bone scintigraphy and CT of the chest and abdomen, with MRI being used in selected cases for suspected neurological or bone involvement. The role of imaging studies in this setting is to confirm the recurrence and to assess whether the disease is localized or systemic (Fig. 2a). The presence of visceral metastases is also associated with a poor prognosis, and this may influence the choice of therapy. Several retrospective studies published in recent years suggest that ${ }^{18} \mathrm{~F}-\mathrm{FDG}-\mathrm{PET}$ is an accurate imaging modality for detecting recurrent breast cancer [63-67]. Kamel and colleagues studied 60 consecutive patients with suspected recurrent breast cancer. They found accuracies of $89 \%$ and $98 \%$ for the detection of local and metastatic recurrences, respectively [68]. In 57 patients, Siggelkow found a sensitivity of $81 \%$ and a specificity of $98 \%$ for PET imaging [66]. Eubank and colleagues showed that PET was more accurate than CT in detecting involvement in mediastinal and internal mammary nodes [69]. ${ }^{18}$ FDG-PET may also be useful in distinguishing between radiation-induced and metastatic brachial plexopathy [70].

Cook and colleagues compared 18F-FDG-PET imaging with bone scintigraphy to detect bone metastases in 23 patients [71]. They found on average nearly twice as many lesions 
with PET than with bone scintigraphy, and PET was more sensitive in detecting osteolytic lesions. However, several osteoblastic bone metastases depicted by bone scintigraphy were missed by PET imaging. In 48 patients with suspected bone metastases, Yang and colleagues concluded that ${ }^{18} \mathrm{~F}$ FDG-PET was as sensitive as the bone scan but more specific for the detection of bone metastases [72].

\section{Assessment of response to therapy}

PET imaging has also been proposed as an alternative for the rapid assessment of tumor response to chemotherapy: a reduction in ${ }^{18} \mathrm{~F}-\mathrm{FDG}$ uptake has been postulated to predict the eventual clinical or pathological response [73,74]. Wahl and colleagues studied 11 patients with locally advanced breast cancer, treated with hormone chemotherapy [73]. They observed a significant decrease in ${ }^{18} \mathrm{~F}-\mathrm{FDG}$ uptake in responders after one cycle of chemotherapy and no significant decrease in non-responders. Smith and colleagues studied 30 patients with large primary tumors or locally advanced disease treated with neoadjuvant chemotherapy. After one cycle of chemotherapy, a reduction of ${ }^{18} \mathrm{~F}-\mathrm{FDG}$ had a high sensitivity for the prediction of a complete pathologic response [75]. Similar results were reported by Schelling and colleagues after the first and second courses of chemotherapy in 22 patients [76]. Mankoff studied tumor blood flow and glucose metabolism by PET to assess whether these parameters are predictive of the response to chemotherapy in locally advanced breast cancer [77]. They found that tumors with high ${ }^{18}$ F-FDG uptake had a poorer response to chemotherapy. Patients with a low uptake rate of FDG associated with increased blood flow in their tumors were more likely to experience a complete response.

${ }^{18} \mathrm{~F}-\mathrm{FDG}$-PET has also been evaluated as a tool with which to monitor the response of breast cancer bone metastases to therapy. Preliminary results by Stafford and colleagues showed a correlation of changes in FDG uptake after therapy with the overall clinical assessment [78]. Results also showed a strong correlation between the change in FDG uptake by bone metastases and the percentage of change in tumor marker CA 27.29.

\section{Imaging estrogen receptor expression}

A few groups have developed radiopharmaceuticals for the assessment of ERs, including radio-iodinated ligands for scintigraphy, and fluorinated ligands for PET imaging [79]. Ribeiro-Barras and colleagues demonstrated that $17 \alpha$ [123|]iodovinyl-11 $\beta$-methoxyestradiol (MIVE) scintigraphy could be used in patients to assess the presence of the estrogen receptor (ER) in primary and metastatic breast cancers [80]. Using a more selective stereoisomer, Nachar and colleagues showed that the uptake of MIVE on scintigraphy correlated well with in vitro results of ER concentration [81]. Bennink and colleagues, in a study with 23 subjects, showed that patients with high initial uptake of MIVE and complete blockage of MIVE incorporation after initiation of treatment with tamoxifen had a significantly longer progression-free interval than those with low uptake of the tracer and partial or incomplete blockage under therapy [82].

A series of several radiofluorinated estrogen ligands were developed by Katzenellenbogen and Welch in St Louis; their most promising compound was ${ }^{18} \mathrm{~F}$-FES (see Fig. $2 \mathrm{~b}$ ). ${ }^{18} \mathrm{~F}$ FES had a high affinity for the ER and a good chemical stability in vivo $[83,84]$. Mintun and colleagues showed that ${ }_{18}^{18} \mathrm{~F}-\mathrm{FES}$ uptake could detect ER-positive breast tumors [85], and could assess ER expression in nodal and distant metastases [86]. Dehdashti and colleagues confirmed the excellent correspondence (88\%) between ER status determined by ${ }^{18} \mathrm{~F}-\mathrm{FES}-\mathrm{PET}$ imaging and in vitro results from biopsy samples [87]. Because ${ }^{18} \mathrm{~F}-\mathrm{FES}$ is rapidly metabolized in the blood, other analogs have been synthesized with fluorine substituents at the 2 and 4 ring positions to resist metabolic inactivation, and with a methoxy group at position 11 to reduce non-specific binding $[88,89]$. Derivatives of fulvestrant (Faslodex ${ }^{\circledR}$; AstraZeneca) have also been labeled to assess the potential response of breast cancers to this pure anti-estrogen [90], but in vivo results were disappointing [91].

Because the ER status of primary breast tumors is almost always known from a histopathology specimen, ${ }^{18} \mathrm{~F}-\mathrm{FES}$ and other ER-binding analogs add little to the initial diagnosis of breast cancer. The key potential role of these ligands is to assess recurrent breast cancer in women with a history of an ER-positive primary tumor. ER imaging with PET can confirm the ER positivity of sites that are inaccessible to biopsy and can demonstrate in vivo the heterogeneity of ER expression. Clinical trials are under way to assess whether ER imaging with PET can predict the outcome of first-line or second -line hormone therapy in women with recurrent breast cancer. Mortimer and colleagues reported a study with combined ${ }^{18} \mathrm{~F}$ FDG and ${ }^{18} \mathrm{~F}-\mathrm{FES}$ imaging for the evaluation of therapy response to tamoxifen in 40 women with breast cancer [92]. A successful response to tamoxifen was associated with ER blockage and a metabolic 'flare' response (increased ${ }^{18} \mathrm{~F}$ FDG uptake) 7 to 10 days after the initiation of tamoxifen.

\section{Radiolabeled nucleosides and amino acids $\left[{ }^{18}\right.$ F]Fluorothymidine}

${ }^{18} \mathrm{~F}-\mathrm{FLT}$ has been proposed by Shields and colleagues to image tumor proliferation in vivo by PET [11]. Although ${ }^{18} \mathrm{~F}$ FLT is not directly incorporated into DNA and rather reflects thymidine kinase- 1 activity, the uptake of this radiotracer has been shown to correlate well with the percentage of cells in $\mathrm{S}$ phase [93]. Vesselle and colleagues recently reported that, in 10 patients with non small cell lung cancer, ${ }^{18} \mathrm{~F}-\mathrm{FLT}$ activity correlated well with Ki-67 staining by immunohistochemistry, which reflects proliferative activity [94]. Thus, ${ }^{18} \mathrm{~F}-\mathrm{FLT}$ seems to be a promising agent for measuring cellular proliferation and for the early assessment of therapy effectiveness. In a clinical study [95] evaluating the use of ${ }^{18} \mathrm{~F}-\mathrm{FLT}$ as a PET 
tracer for the diagnosis of breast cancer (12 patients: T2 to T4) in comparison with $18 \mathrm{~F}-\mathrm{FDG}, 93 \%$ of primary tumors demonstrated focally increased ${ }^{18} \mathrm{~F}$-FLT uptake and $88 \%$ with histologically proven axillary lymph node metastases showed focally increased uptake of ${ }^{18} \mathrm{~F}$-FLT. In direct comparison with ${ }^{18} \mathrm{~F}-\mathrm{FDG}$, the ${ }^{18} \mathrm{~F}-\mathrm{FLT}$ activity was lower than that of ${ }^{18} \mathrm{~F}-\mathrm{FDG}$ in most primary tumor sites and axillary lymph node metastases, but tumor contrast was comparable to that of ${ }^{18} \mathrm{~F}-\mathrm{FDG}$. This first available study using ${ }^{18} \mathrm{~F}-\mathrm{FLT}$ as a PET tracer in breast cancer concluded that ${ }^{18} \mathrm{~F}$-FLT-PET seems to be suitable for the diagnosis of primary breast cancer and locoregional metastases, but further studies are required to validate this hypothesis.

\section{Radiolabeled amino acids}

Various radiolabeled amino acids were developed for breast cancer detection with PET. However, few studies compared these radiopharmaceuticals with other diagnostic methods. Those radiolabeled amino acids studied in breast cancer include L-[18 $\mathrm{F}] \alpha$-methyltyrosine [96], [ $\left.{ }^{11} \mathrm{C}\right]$ methionine [96,97], [18F]fluoroalanine [98] and [11 C]tyrosine [99]. During chemotherapy courses, the uptake of $\left[{ }^{11} \mathrm{C}\right]$ methionine from metastases decreased in cases of stable or responsive disease and increased in cases of progressive disease [97]. This led the authors to conclude that metabolic changes in radiolabeled amino acid incorporation measured by PET preceded the clinical response. Studies of the distribution of $\left[{ }^{18} \mathrm{~F}\right]$ fluoroalanine in tissue showed that the tumor: tissue ratio increased as a function of time, suggesting that this tracer could be of interest in detecting breast cancer [98]. $\left[{ }^{11} \mathrm{C}\right]$ Tyrosine seemed to visualize malignant breast tumors as effectively as ${ }^{18} \mathrm{~F}-\mathrm{FDG}$, but the visual contrast was better with ${ }^{18} \mathrm{~F}-\mathrm{FDG}$. [ $\left.{ }^{11} \mathrm{C}\right]$ Tyrosine had a lower uptake in fibrocystic disease than ${ }^{18} \mathrm{~F}-\mathrm{FDG}$, which could reduce false-positive studies. No difference in the tumor: non-tumor ratio was found between the two tracers [99].

\section{Other receptors as targets for diagnostic imaging \\ Sigma receptors}

Sigma receptors $(\sigma)$ constitute a family of binding sites initially considered as a subtype of opiate receptors, and both subtypes $\left(\sigma_{1}\right.$ and $\left.\sigma_{2}\right)$ are expressed in very high concentrations on human breast cancer cell lines [100]. John and colleagues observed high levels of $\sigma_{1}$ and $\sigma_{2}$ receptors on primary breast tumors from four patients [101]. Healthy breast tissues did not express specific binding for $\sigma$ receptor ligands. With a monoclonal antibody directed to the $\sigma_{1}$ receptor, Simony-Lafontaine and colleagues showed, on tumor specimens from 95 breast cancer patients, a positive correlation between progesterone receptor positivity and the presence of $\sigma_{1}$ receptors [102].

John and colleagues initiated the first studies to assess $\sigma$ ligands for the diagnostic imaging of cancer. They developed detection of breast cancer [103-105]. Caveliers and colleagues recently published the first clinical imaging study evaluating a non-selective $\sigma$ ligand labeled with iodine-123 in patients with breast cancer [106]. Their preliminary results, obtained in 10 patients in planar mode, showed the detection of 8 of 10 breast cancers, despite the limited spatial resolution of planar imaging. No radiotracer uptake was noted in fibrocystic disease or inflammatory adenitis, which can cause false positive results on ${ }^{18} \mathrm{~F}-\mathrm{FDG}$-PET studies. Collier and colleagues synthesized a highly selective $\sigma_{1}$ ligand labeled with fluorine-18 for PET imaging of $\sigma$ receptors [107]. Preliminary results for the detection of spontaneous breast tumors occurring in transgenic MMTV mice were promising with 1-(3-[18F]fluoropropyl)-4-(4-cyanophenoxymethyl)-piperidine [108]. Shiue and colleagues reported promising results for imaging human breast tumors implanted in SCID mice with $N(N$-benzylpiperidine-4-yl)2-[18F]fluorobenzamide [109,110].

\section{Other molecular targets}

Several other ligands are being evaluated for the molecular characterization of breast cancer: among many others, these include ligands for assessing the HER2/neu status of breast cancers [111], radiolabeled metalloproteinase inhibitors to measure invasion capacity [112] and labeled peptides to detect cell surface receptors that are overexpressed in breast cancer cells [113]. The key advantage of PET and SPECT over other imaging methods lies in their ability to measure nanomolar concentrations of cellular receptors or enzymes without saturating the system under study. This allows radiochemists to follow new developments in molecular therapeutics with radiolabeled analogs of potentially therapeutic compounds to provide non-invasive in vivo characterization of breast cancers. Given the highly variable clinical evolution of this disease, such information may eventually serve to individualize the therapeutic approach by providing functional information about the status of a specific receptor or enzyme across tumor sites.

\section{Conclusion}

Planar scintigraphy, SPECT and PET can each be useful as adjunct imaging methods for detecting and staging primary breast cancer, but they cannot currently replace invasive procedures because of an insufficient sensitivity to detect small (less than $1 \mathrm{~cm}$ ) tumor deposits. SMM is a useful tool for assessing palpable breast masses in women with dense breasts and for evaluating a suspected recurrence in a treated breast when mammography is equivocal or negative. 18F-FDG-PET imaging can confirm and restage suspected recurrences, and can provide an early assessment of the effectiveness of a new treatment regimen. Other tracers, such as radiolabeled estrogens, amino acids and nucleosides, may be more specific than ${ }^{18} \mathrm{~F}-\mathrm{FDG}$; further clinical studies will be of interest for the assessment of their potential roles in the detection of primary breast cancer and the prediction or evaluation of response to therapy. As new molecular targets are identified and new radioligands synthesized for SPECT 
This article is part of a review series on Imaging in breast cancer, edited by David A Mankoff.

Other articles in the series can be found online at http://breast-cancer-research.com/articles/ review-series.asp?series=bcr_imaging

and PET imaging, this field is likely to expand with selective ligands targeting proteins that are overexpressed in breast cancer cells. The challenge will be to follow these developments with well-designed clinical studies to evaluate their relative usefulness with respect to other invasive procedures and non-invasive imaging modalities.

\section{Competing interests}

The author(s) declare that they have no competing interests.

\section{Authors' contributions}

Both authors participated equally in the draft of the manuscript, and read and approved the submitted version.

\section{References}

1. Buist DS, Porter PL, Lehman C, Taplin SH, White E: Factors contributing to mammography failure in women aged 40-49 years. J Natl Cancer Inst 2004, 96:1432-1440.

2. Viale G, Bosari S, Mazzarol G, Galimberti V, Luini A, Veronesi P, Paganelli G, Bedoni M, Orvieto E: Intraoperative examination of axillary sentinel lymph nodes in breast carcinoma patients. Cancer 1999, 85:2433-2438.

3. Altinyollar H, Kapucuoglu N, Pak I, Berberoglu U: Lymphatic mapping and sentinel lymphadenectomy in early stage breast carcinoma. J Exp Clin Cancer Res 2000, 19:141-144.

4. Weaver DL, Krag DN, Ashikaga T, Harlow SP, O'Connell M: Pathologic analysis of sentinel and nonsentinel lymph nodes in breast carcinoma: a multicenter study. Cancer 2000, 88: 1099-1107.

5. Hsieh PP, Ho WL, Yeh DC, Liu TJ, Wu CC, Lin JH, Wang SJ: Histopathologic analysis of sentinel lymph nodes in breast carcinoma. Chung Hua I Hsueh Tsa Chih (Taipei) 2000, 63: 744-750.

6. Canadian Cancer Statistics 2005 [http://www.cancer.ca]

7. Fisher B, Osborne K, Margolese R, Bloomer W: Neoplasms of the breast. In Cancer Medicine. Vol. 1. 4th edition. Edited by Holland J, Blast R, Morton D, Frei E, Kuge D, Weichselbaum R. Baltimore: Williams \& Wilkins; 1997:2349-2429.

8. Jardines L, Callans LS, Torosian MH: Recurrent breast cancer: presentation, diagnosis, and treatment. Semin Oncol 1993, 20: 538-547.

9. Peters W: Management of metastatic breast cancer. Adv Intern Med 1995, 40:341-364.

10. Hustinx R, Benard F, Alavi A: Whole-body FDG-PET imaging in the management of patients with cancer. Semin Nucl Med 2002, 32:35-46.

11. Shields AF, Grierson JR, Dohmen BM, Machulla HJ, Stayanoff JC, Lawhorn-Crews JM, Obradovich JE, Muzik O, Mangner TJ: Imaging proliferation in vivo with [F-18]FLT and positron emission tomography. Nat Med 1998, 4:1334-1336.

12. Kieswetter D, Kilbourn M, Landvatter S, Heiman D, Katzenellenbogen J, Welch M: Preparation of four fluorine-18-labeled estrogens and their selective uptake in target tissues of immature rats. J Nucl Med 1984, 25:1212-1221.

13. Liberman M, Sampalis F, Mulder DS, Sampalis JS: Breast cancer diagnosis by scintimammography: a meta-analysis and review of the literature. Breast Cancer Res Treat 2003, 80:115-126.

14. Bender H, Friedrich E, Zamora PO, Guhlke S, Biersack HJ: Effects of induction of multi-drug resistance on accumulation of ${ }^{99 \mathrm{~m} T c-s e s t a m i b i}$ in vitro. Anticancer Res 1997, 17:18331839.
15. Chiu ML, Kronauge JF, Piwnica-Worms D: Effect of mitochondrial and plasma membrane potentials on accumulation of hexakis (2-methoxyisobutylisonitrile) technetium(I) in cultured mouse fibroblasts. J Nucl Med 1990, 31:1646-1653.

16. Maublant JC, Zhang Z, Rapp M, Ollier M, Michelot J, Veyre A: In vitro uptake of technetium-99m-teboroxime in carcinoma cell lines and normal cells: comparison with technetium-99m-sestamibi and thallium-201. J Nucl Med 1993, 34:1949-1952.

17. Piwnica-Worms D, Chiu ML, Croop JM, Kronauge JF: Enhancement of Tc-99m-sestamibi accumulation in multidrug resistant (MDR) cells by cytotoxic drugs and MDR reversing agents. J Nucl Med 1993, 34:140P.

18. Palmedo $H$, Bender $H$, Grunwald $F$, Mallmann $P$, Zamora $P$, Krebs $\mathrm{D}$, Biersack HJ: Comparison of fluorine-18 fluorodeoxyglucose positron emission tomography and technetium-99m methoxyisobutylisonitrile scintimammography in the detection of breast tumours. Eur J Nucl Med 1997, 24:1138-1145.

19. Yutani K, Shiba E, Kusuoka H, Tatsumi M, Uehara T, Taguchi T, Takai SI, Nishimura T: Comparison of FDG-PET with MIBISPECT in the detection of breast cancer and axillary lymph node metastasis. J Comput Assist Tomogr 2000, 24:274-280.

20. Danielsson R, Bone B, Perbeck L, Aspelin P: Evaluation of planar scintimammography with $99 \mathrm{mTc}-\mathrm{MIBI}$ in the detection of axillary lymph node metastases of breast carcinoma. Acta Radiol 1999, 40:491-495.

21. Taillefer R, Robidoux A, Turpin S, Lambert R, Cantin J, Leveille J: Metastatic axillary lymph node technetium-99m-MIBI imaging in primary breast cancer. J Nucl Med 1998, 39:459-464.

22. Schillaci O, Scopinaro F, Danieli R, Tavolaro R, Picardi V, Cannas $\mathrm{P}$, Colella AC: ${ }^{99 \mathrm{mTC}}$-sestamibi scintimammography in patients with suspicious breast lesions: comparison of SPET and planar images in the detection of primary tumours and axillary lymph node involvement. Nucl Med Commun 1997, 18:839845.

23. Cwikla JB, Buscombe JR, Kolasinska AD, Holloway B, Hilson AJ: Evaluation of scintimammography as an additional test to conventional mammography in detection of breast cancer [in Polish]. Ginekol Pol 2003, 74:362-370.

24. Fondrinier E, Muratet JP, Anglade E, Fauvet R, Berger V, Lorimier $G$, Jallet $P$ : Clinical experience with $99 \mathrm{mTc}-\mathrm{MIBI}$ scintimammography in patients with breast microcalcifications. Breast 2004, 13:316-320.

25. Palmedo H, Biersack HJ, Lastoria S, Maublant J, Prats E, Stegner HE, Bourgeois P, Hustinx R, Hilson AJ, Bischof-Delaloye A: Scintimammography with technetium-99m methoxyisobutylisonitrile: results of a prospective European multicentre trial. Eur $J$ Nucl Med 1998, 25:375-385.

26. Tiling R, Linke R, Kessler M, Untch M, Sommer H, Brinkbaumer $\mathrm{K}$, Becker I, Hahn K: Breast scintigraphy using 99mTc-sestamibi use and limitations [in German]. Nuklearmedizin 2002, 41:148156.

27. Mankoff DA, Dunnwald LK, Gralow JR, Ellis GK, Drucker MJ, Livingston RB: Monitoring the response of patients with locally advanced breast carcinoma to neoadjuvant chemotherapy using [technetium 99m]-sestamibi scintimammography. Cancer 1999, 85:2410-2423.

28. Wilczek B, von Schoultz E, Bergh J, Eriksson E, Larsson SA, Jacobsson $\mathrm{H}$ : Early assessment of neoadjuvant chemotherapy by FEC-courses of locally advanced breast cancer using 99mTc-MIBI. Acta Radio/ 2003, 44:284-287.

29. Marshall C, Eremin J, El-Sheemy M, Eremin O, Griffiths PA: Monitoring the response of large $(>3 \mathrm{~cm})$ and locally advanced (T34 , N0-2) breast cancer to neoadjuvant chemotherapy using 99mTc-Sestamibi uptake. Nucl Med Commun 2005, 26:9-15.

30. Dunnwald LK, Gralow JR, Ellis GK, Livingston RB, Linden HM, Lawton TJ, Barlow WE, Schubert EK, Mankoff DA: Residual tumor uptake of $\left[{ }^{99} \mathrm{mTc}\right]$-sestamibi after neoadjuvant chemotherapy for locally advanced breast carcinoma predicts survival. Cancer 2005, 103:680-688.

31. Kao CH, Tsai SC, Liu TJ, Ho YJ, Wang JJ, Ho ST, ChangLai SP: P-glycoprotein and multidrug resistance-related protein expressions in relation to technetium-99m methoxyisobutylisonitrile scintimammography findings. Cancer Res 2001, 61:1412-1414.

32. Cwikla JB, Kolasinska A, Buscombe JR, Hilson AJ: Tc-99m MIBI in suspected recurrent breast cancer. Cancer Biother Radiopharm 2000, 15:367-372. 
33. Gallagher BM, Fowler JS, Gutterson NI, MacGregor RR, Wan CN, Wolf AP: Metabolic trapping as a principle of radiopharmaceutical design: some factors responsible for the biodistribution of [18F]deoxyglucose. J Nucl Med 1978, 19:1154-1161.

34. Phelps ME, Huang SC, Hoffman EJ, Selin C, Sokoloff L, Kuhl DE: Tomographic measurement of local cerebral glucose metabolic rate in humans with (F-18)2-fluoro-2-deoxy-D-glucose: validation of method. Ann Neurol 1979, 6:371-388.

35. Wahl RL, Hutchins GD, Buchsbaum DJ, Liebert M, Grossman HB, Fisher S: ${ }^{18} \mathrm{~F}-2$-deoxy-2-fluoro-D-glucose uptake into human tumor xenografts. Feasibility studies for cancer imaging with positron-emission tomography. Cancer 1991, 67:1544-1550.

36. Brown RS, Leung JY, Fisher SJ, Frey KA, Ethier SP, Wahl RL: Intratumoral distribution of tritiated fluorodeoxyglucose in breast carcinoma: I. Are inflammatory cells important? J Nucl Med 1995, 36:1854-1861.

37. Clavo AC, Brown RS, Wahl RL: Fluorodeoxyglucose uptake in human cancer cell lines is increased by hypoxia. J Nucl Med 1995, 36:1625-1632.

38. Higashi K, Clavo AC, Wahl RL: Does FDG uptake measure proliferative activity of human cancer cells? In vitro comparison with DNA flow cytometry and tritiated thymidine uptake. J Nucl Med 1993, 34:414-419.

39. Avril N, Menzel M, Dose J, Schelling M, Weber W, Janicke F, Nathrath W, Schwaiger M: Glucose metabolism of breast cancer assessed by ${ }^{18}$ F-FDG PET: histologic and immunohistochemical tissue analysis. J Nucl Med 2001, 42:9-16.

40. Crippa F, Seregni E, Agresti R, Chiesa C, Pascali C, Bogni A, Decise D, De Sanctis V, Greco M, Daidone MG, et al:: Association between $\left[{ }^{18} \mathrm{~F}\right]$ fluorodeoxyglucose uptake and postoperative histopathology, hormone receptor status, thymidine labelling index and p53 in primary breast cancer: a preliminary observation. Eur J Nucl Med 1998, 25:1429-1434.

41. Adler LP, Crowe JP, al-Kaisi NK, Sunshine JL: Evaluation of breast masses and axillary lymph nodes with [F-18] 2-deoxy2-fluoro-D-glucose PET. Radiology 1993, 187:743-750.

42. Crowe JP Jr, Adler LP, Shenk RR, Sunshine J: Positron emission tomography and breast masses: comparison with clinical, mammographic, and pathological findings. Ann Surg Oncol 1994, 1:132-140.

43. Nieweg OE, Kim EE, Wong WH, Broussard WF, Singletary SE, Hortobagyi GN, Tilbury RS: Positron emission tomography with fluorine-18-deoxyglucose in the detection and staging of breast cancer. Cancer 1993, 71:3920-3925.

44. Scheidhauer K, Scharl A, Pietrzyk U, Wagner R, Gohring UJ, Schomacker K, Schicha H: Qualitative [18F]FDG positron emission tomography in primary breast cancer: clinical relevance and practicability. Eur J Nucl Med 1996, 23:618-623.

45. Tse NY, Hoh CK, Hawkins RA, Zinner MJ, Dahlbom M, Choi Y, Maddahi J, Brunicardi FC, Phelps ME, Glaspy JA: The application of positron emission tomographic imaging with fluorodeoxyglucose to the evaluation of breast disease. Ann Surg 1992, 216:27-34.

46. Wahl RL, Cody RL, Hutchins GD, Mudgett EE: Primary and metastatic breast carcinoma: initial clinical evaluation with PET with the radiolabeled glucose analogue 2-[F-18]-fluoro2-deoxy-D-glucose. Radiology 1991, 179:765-770.

47. Avril N, Rose CA, Schelling M, Dose J, Kuhn W, Bense S, Weber W, Ziegler S, Graeff H, Schwaiger M: Breast imaging with positron emission tomography and fluorine-18 fluorodeoxyglucose: use and limitations. J Clin Oncol 2000, 18:3495-3502.

48. Schirrmeister $H$, Kuhn $T$, Guhlmann $A$, Santjohanser $C$, Horster $T$, Nussle K, Koretz K, Glatting G, Rieber A, Kreienberg R, et al:: Fluorine-18 2-deoxy-2-fluoro-D-glucose PET in the preoperative staging of breast cancer: comparison with the standard staging procedures. Eur J Nucl Med 2001, 28:351-358.

49. Brix G, Henze M, Knopp MV, Lucht R, Doll J, Junkermann $H$, Hawighorst $\mathrm{H}$, Haberkorn U: Comparison of pharmacokinetic MRI and $\left.{ }^{18} \mathrm{~F}\right]$ fluorodeoxyglucose PET in the diagnosis of breast cancer: initial experience. Eur Radiol 2001, 11:20582070.

50. Weinberg I, Majewski S, Weisenberger A, Markowitz A, Aloj L, Majewski L, Danforth D, Mulshine J, Cowan K, Zujewski J, et al.: Preliminary results for positron emission mammography: real-time functional breast imaging in a conventional mammography gantry. Eur J Nucl Med 1996, 23:804-806.
51. Murthy K, Aznar M, Thompson CJ, Loutfi A, Lisbona R, Gagnon $\mathrm{JH}$ : Results of preliminary clinical trials of the positron emission mammography system PEM-I: a dedicated breast imaging system producing glucose metabolic images using FDG. J Nucl Med 2000, 41:1851-1858.

52. Levine EA, Freimanis RI, Perrier ND, Morton K, Lesko NM Bergman S, Geisinger KR, Williams RC, Sharpe C, Zavarzin V, et al.: Positron emission mammography: initial clinical results. Ann Surg Oncol 2003, 10:86-91.

53. Rosen EL, Turkington TG, Soo MS, Baker JA, Coleman RE: Detection of primary breast carcinoma with a dedicated, large-field-of-view FDG PET mammography device: initial experience. Radiology 2005, 234:527-534.

54. Weinberg IN, Beylin D, Zavarzin V, Yarnall S, Stepanov PY Anashkin E, Narayanan D, Dolinsky S, Lauckner K, Adler LP Positron emission mammography: high-resolution biochemical breast imaging. Techno/ Cancer Res Treat 2005, 4:55-60.

55. Adler LP, Faulhaber PF, Schnur KC, Al-Kasi NL, Shenk RR: Axillary lymph node metastases: screening with [F-18]2-deoxy-2fluoro-D-glucose (FDG) PET. Radiology 1997, 203:323-327.

56. Avril N, Dose J, Janicke F, Bense S, Ziegler S, Laubenbacher C, Romer W, Pache H, Herz M, Allgayer B, et al:: Metabolic characterization of breast tumors with positron emission tomography using F-18 fluorodeoxyglucose. J Clin Oncol 1996, 14: 1848-1857.

57. Utech $\mathrm{Cl}$, Young CS, Winter PF: Prospective evaluation of fluorine-18 fluorodeoxyclucose positron emission tomography in breast cancer for staging of the axilla related to surgery and immunocytochemistry. Eur J Nucl Med 1996, 23:1588-1593.

58. Greco M, Crippa F, Agresti R, Seregni E, Gerali A, Giovanazzi R, Micheli A, Asero S, Ferraris C, Gennaro M, et al:: Axillary lymph node staging in breast cancer by 2-fluoro-2-deoxy-D-glucosepositron emission tomography: clinical evaluation and alternative management. J Natl Cancer Inst 2001, 93:630-635.

59. Fehr MK, Hornung R, Varga Z, Burger D, Hess T, Haller U, Fink D, von Schulthess GK, Steinert HC: Axillary staging using positron emission tomography in breast cancer patients qualifying for sentinel lymph node biopsy. Breast J 2004, 10:89-93.

60. Barranger E, Grahek D, Antoine M, Montravers F, Talbot JN, Uzan $\mathrm{S}$ : Evaluation of fluorodeoxyglucose positron emission tomography in the detection of axillary lymph node metastases in patients with early-stage breast cancer. Ann Surg Oncol 2003, 10:622-627.

61. Wahl RL, Siegel BA, Coleman RE, Gatsonis CG, Group PETS: Prospective multicenter study of axillary nodal staging by positron emission tomography in breast cancer: a report of the staging breast cancer with PET Study Group. J Clin Oncol 2004, 22:277-285.

62. Lovrics PJ, Chen V, Coates G, Cornacchi SD, Goldsmith CH, Law C, Levine MN, Sanders K, Tandan VR: A prospective evaluation of positron emission tomography scanning, sentinel lymph node biopsy, and standard axillary dissection for axillary staging in patients with early stage breast cancer. Ann Surg Oncol 2004, 11:846-853.

63. Bender $H$, Kirst $J$, Palmedo $H$, Schomburg $A$, Wagner $U$, Ruhlmann J, Biersack $\mathrm{HJ}$ : Value of 18fluoro-deoxyglucose positron emission tomography in the staging of recurrent breast carcinoma. Anticancer Res 1997, 17:1687-1692.

64. Kim TS, Moon WK, Lee DS, Chung JK, Lee MC, Youn YK, Oh SK, Choe KJ, Noh DY: Fluorodeoxyglucose positron emission tomography for detection of recurrent or metastatic breast cancer. World J Surg 2001, 25:829-834.

65. Moon D, Hoh C, Silverman D, Glaspy J, Phelps M, Maddahi J: Accuracy of whole-body FDG PET for the detection of recurrent or metastatic breast carcinoma [abstract]. J Nucl Med 1996, 37:99P.

66. Siggelkow W, Zimny M, Faridi A, Petzold K, Buell U, Rath W: The value of positron emission tomography in the follow-up for breast cancer. Anticancer Res 2003, 23:1859-1867.

67. Suarez M, Perez-Castejon MJ, Jimenez A, Domper M, Ruiz G, Montz R, Carreras JL: Early diagnosis of recurrent breast cancer with FDG-PET in patients with progressive elevation of serum tumor markers. Q J Nucl Med 2002, 46:113-121.

68. Kamel EM, Wyss MT, Fehr MK, von Schulthess GK, Goerres GW: $\left[{ }^{18} \mathrm{~F}\right]$-Fluorodeoxyglucose positron emission tomography in patients with suspected recurrence of breast cancer. $J$ Cancer Res Clin Oncol 2003, 129:147-153. 
69. Eubank WB, Mankoff DA, Takasugi J, Vesselle H, Eary JF, Shanley TJ, Gralow JR, Charlop A, Ellis GK, Lindsley KL, et al:: ${ }^{18} \mathrm{Fluo-}$ rodeoxyglucose positron emission tomography to detect mediastinal or internal mammary metastases in breast cancer. J Clin Oncol 2001, 19:3516-3523.

70. Ahmad A, Barrington S, Maisey M, Rubens RD: Use of positron emission tomography in evaluation of brachial plexopathy in breast cancer patients. Br J Cancer 1999, 79:478-482.

71. Cook GJ, Houston S, Rubens R, Maisey MN, Fogelman I: Detection of bone metastases in breast cancer by ${ }^{18}$ FDG PET: differing metabolic activity in osteoblastic and osteolytic lesions. J Clin Oncol 1998, 16:3375-3379.

72. Yang SN, Liang JA, Lin FJ, Kao CH, Lin CC, Lee CC: Comparing whole body ${ }^{18} \mathrm{~F}-2$-deoxyglucose positron emission tomography and technetium-99m methylene diphosphonate bone scan to detect bone metastases in patients with breast cancer. J Cancer Res Clin Oncol 2002, 128:325-328.

73. Wahl RL, Zasadny K, Helvie M, Hutchins GD, Weber B, Cody R: Metabolic monitoring of breast cancer chemohormonotherapy using positron emission tomography: initial evaluation. $J$ Clin Oncol 1993, 11:2101-2111.

74. Jansson $\mathrm{T}$, Westlin JE, Ahlstrom $\mathrm{H}$, Lilja A, Langstrom B, Bergh J: Positron emission tomography studies in patients with locally advanced and/or metastatic breast cancer: a method for early therapy evaluation? J Clin Oncol 1995, 13:1470-1477.

75. Smith IC, Welch AE, Hutcheon AW, Miller ID, Payne S, Chilcott F, Waikar S, Whitaker T, Ah-See AK, Eremin O, et al.: Positron emission tomography using $\left[{ }^{18} \mathrm{~F}\right]$-fluorodeoxy-D-glucose to predict the pathologic response of breast cancer to primary chemotherapy. J Clin Oncol 2000, 18:1676-1688.

76. Schelling M, Avril N, Nahrig J, Kuhn W, Romer W, Sattler D, Werner M, Dose J, Janicke F, Graeff H, et al:: Positron emission tomography using [18F]fluorodeoxyglucose for monitoring primary chemotherapy in breast cancer. J Clin Oncol 2000, 18: 1689-1695.

77. Mankoff DA, Dunnwald LK, Gralow JR, Ellis GK, Charlop A, Lawton TJ, Schubert EK, Tseng J, Livingston RB: Blood flow and metabolism in locally advanced breast cancer: relationship to response to therapy. J Nucl Med 2002, 43:500-509.

78. Stafford SE, Gralow JR, Schubert EK, Rinn KJ, Dunnwald LK, Livingston RB, Mankoff DA: Use of serial FDG PET to measure the response of bone-dominant breast cancer to therapy. Acad Radiol 2002, 9:913-921.

79. Van de Wiele C, De Vos F, Slegers G, Van Belle S, Dierckx RA: Radiolabeled estradiol derivatives to predict response to hormonal treatment in breast cancer: a review. Eur J Nucl Med 2000, 27:1421-1433.

80. Ribeiro-Barras MJ, Foulon C, Baulieu JL, Guilloteau D, Bougnoux $\mathrm{P}$, Lansac J, Besnard JC: Estrogen receptor imaging with 17 alpha-[123]]iodovinyl-11 beta-methoxyestradiol (MIVE2)-Part II. Preliminary results in patients with breast carcinoma. Int $J$ Radiat Applic Instrum B Nucl Med Biol 1992, 19:263-267.

81. Nachar O, Rousseau JA, Ouellet R, Rioux A, Lefebvre B, Ali $H$, van Lier JE: Scintimammography with 11beta-methoxy-(17alpha,20Z)[123|]iodovinylestradiol: a complementary role to $99 \mathrm{mTC}$ methoxyisobutyl isonitrile in the characterization of breast tumors. J Nucl Med 2000, 41:1324-1331.

82. Bennink RJ, van Tienhoven G, Rijks LJ, Noorduyn AL, Janssen AG, Sloof GW: In vivo prediction of response to antiestrogen treatment in estrogen receptor-positive breast cancer. $J$ Nucl Med 2004, 45:1-7.

83. Kieswetter D, Katzenellenbogen J, Kilbourn M, Welch M: Fluorine-18 labeled estrogen: stereochemical and radiochemical considerations in the preparation of fluorine-18 labeled 16fluoro estrogens by fluoride ion displacement reactions. $J$ Org Chem 1984, 49:4900-4905.

84. Tewson T: Synthesis of 16-alpha-fluoroestradiol (abstract). J Nucl Med 1983, 24:P52.

85. Mintun MA, Welch MJ, Siegel BA, Mathias CJ, Brodack JW, McGuire $\mathrm{AH}$, Katzenellenbogen JA: Breast cancer: PET imaging of estrogen receptors. Radiology 1988, 169:45-48.

86. McGuire AH, Dehdashti F, Siegel BA, Lyss AP, Brodack JW, Mathias CJ, Mintun MA, Katzenellenbogen JA, Welch MJ: Positron tomographic assessment of 16 alpha-[ $\left.{ }^{18} \mathrm{~F}\right]$ fluoro- 17 beta-estradiol uptake in metastatic breast carcinoma. J Nucl Med 1991, 32:1526-1531.

87. Dehdashti F, Mortimer JE, Siegel BA, Griffeth LK, Bonasera TJ,
Fusselman MJ, Detert DD, Cutler PD, Katzenellenbogen JA Welch MJ: Positron tomographic assessment of estrogen receptors in breast cancer: comparison with FDG-PET and in vitro receptor assays. J Nucl Med 1995, 36:1766-1774.

88. Seimbille Y, Rousseau J, Bénard F, Ali H, van Lier JE: Synthesis of 2,16 alpha- and 4,16 alpha-[16alpha- ${ }^{-18} \mathrm{~F}$ ]difluoroestradiols and their 11 beta-methoxy derivatives for estrogen receptor imaging. J Labelled Cpd Radiopharm 2001, 44:S348-S350.

89. Seimbille $Y$, Bénard F, van Lier JE: Synthesis of 16alpha-fluoro ICI 182,780 derivatives: powerful antiestrogens to image estrogen receptor densities in breast cancer by positron emission tomography. J Chem Soc Perkin Trans / 2002, 20: 2275-2281.

90. Seimbille $Y$, Rousseau J, Benard F, Morin C, Ali H, Avvakumov G Hammond GL, van Lier JE: 18F-labeled difluoroestradiols: preparation and preclinical evaluation as estrogen receptorbinding radiopharmaceuticals. Steroids 2002, 67:765-775.

91. Seimbille Y, Bénard F, Rousseau J, Pépin E, Aliaga A, Tessier G, van Lier JE: Impact on estrogen receptor binding and target tissue uptake of ${ }^{[18}$ F]fluorine substitution at the 16alphaposition of fulvestrant (Faslodex; ICl 182,780). Nucl Med Biol 2004, 31:691-698.

92. Mortimer JE, Dehdashti F, Siegel BA, Trinkaus K, Katzenellenbogen JA, Welch MJ: Metabolic flare: indicator of hormone responsiveness in advanced breast cancer. J Clin Oncol 2001, 19:2797-2803.

93. Rasey JS, Grierson JR, Wiens LW, Kolb PD, Schwartz JL: Validation of FLT uptake as a measure of thymidine kinase-1 activity in A549 carcinoma cells. J Nucl Med 2002, 43:1210-1217.

94. Vesselle H, Grierson J, Muzi M, Pugsley JM, Schmidt RA, Rabinowitz $\mathrm{P}$, Peterson $L M$, Vallieres $E$, Wood $D E$ : In vivo validation of $3^{\prime}$-deoxy-3'-[18 $\left.\mathrm{F}\right]$ fluorothymidine $\left.\left({ }^{18} \mathrm{~F}\right] \mathrm{FLT}\right)$ as a proliferation imaging tracer in humans: correlation of $\left[{ }^{18} \mathrm{~F}\right] \mathrm{FLT}$ uptake by positron emission tomography with Ki-67 immunohistochemistry and flow cytometry in human lung tumors. Clin Cancer Res 2002, 8:3315-3323.

95. Smyczek-Gargya B, Fersis N, Dittmann H, Vogel U, Reischl G, Machulla HJ, Wallwiener D, Bares R, Dohmen BM: PET with [18 $\mathrm{F}]$ fluorothymidine for imaging of primary breast cancer: a pilot study. Eur J Nucl Med Mol Imaging 2004, 31:720-724.

96. Amano S, Inoue T, Tomiyishi K, Ando T, Endo K: In vivo comparison of PET and SPECT radiopharmaceuticals in detecting breast cancer. J Nucl Med 1998, 39:1424-1427.

97. Huovinen R, Leskinen-Kallio $S$, Nagren $K$, Lehikoinen $P$, Ruotsalainen U, Teras M: Carbon-11-methionine and PET in evaluation of treatment response of breast cancer. $\mathrm{Br} J$ Cancer 1993, 67:787-791.

98. Yang D, Kuang LR, Cherif A, Tansey W, Li C, Lin WJ, Liu CW, Kim EE, Wallace $\mathrm{S}$ : Synthesis of ${ }^{\left[{ }^{18} \mathrm{~F}\right] f l u o r o a l a n i n e}$ and [18F]fluorotamoxifen for imaging breast tumors. J Drug Target 1993, 1:259-267.

99. Kole AC, Nieweg OE, Pruim J, Paans AM, Plukker JT, Hoekstra HJ, Schraffordt Koops H, Vaalburg W: Standardized uptake value and quantification of metabolism for breast cancer imaging with FDG and L-[1-11C]tyrosine PET. J NuCl Med 1997, 38:692-696.

100. Vilner BJ, John CS, Bowen WD: Sigma-1 and sigma-2 receptors are expressed in a wide variety of human and rodent tumor cell lines. Cancer Res 1995, 55:408-413.

101. John CS, Vilner BJ, Schwartz AM, Bowen WD: Characterization of sigma receptor binding sites in human biopsied solid tumors [abstract]. J Nucl Med 1996, 37:267P.

102. Simony-Lafontaine J, Esslimani M, Bribes E, Gourgou S, Lequeux N, Lavail R, Grenier J, Kramar A, Casellas P: Immunocytochemical assessment of sigma-1 receptor and human sterol isomerase in breast cancer and their relationship with a series of prognostic factors. Br J Cancer 2000, 82:1958-1966.

103. John CS, Bowen WD, Fisher SJ, Lim BB, Geyer BC, Vilner BJ, Wahl RL: Synthesis, in vitro pharmacologic characterization, and preclinical evaluation of $\mathrm{N}$-[2-(1'-piperidinyl)ethyl]-3[125] ]iodo-4-methoxybenzamide ( $\left.{ }^{\left[{ }^{125}\right.}\right]$ MBA) for imaging breast cancer. Nucl Med Biol 1999, 26:377-382.

104. John CS, Vilner BJ, Bowen WD: Synthesis and characterization of [125I]-N-(N-benzylpiperidin-4-yl)-4- iodobenzamide, a new sigma receptor radiopharmaceutical: high-affinity binding to MCF-7 breast tumor cells. J Medicinal Chem 1994, 37:17371739. 
105. John CS, Vilner BJ, Gulden ME, Efange SM, Langason RB, Moody TW, Bowen WD: Synthesis and pharmacological characterization of 4-[125I]-N-(N-benzylpiperidin-4-yl)-4-iodobenzamide: a high affinity sigma receptor ligand for potential imaging of breast cancer. Cancer Res 1995, 55:3022-3027.

106. Caveliers V, Everaert H, John CS, Lahoutte T, Bossuyt A: Sigma receptor scintigraphy with $\mathrm{N}-\left[2-\left(1^{\prime}\right.\right.$-piperidinyl)ethyl]-3-123|iodo-4-methoxybenzamide of patients with suspected primary breast cancer: first clinical results. J Nucl Med 2002, 43:1647-1649.

107. Collier TL, O'Brien JC, Waterhouse RN: Synthesis of [18F]-1-(3fluoropropyl)-4-(4-cyanophenoxymethyl)-piperidine: a potential sigma-1 receptor radioligand for PET. J Labelled Cpd Radiopharm 1996, 38:785-793.

108. Waterhouse RN, Fawwaz R, Atuahene NF, Liu L, Schmidt AM, Collier TL: Biodistribution and micropet studies of the sigma-1 receptor radiotracer [ $\left.{ }^{18} \mathrm{~F}\right] \mathrm{FPS}$ in the MMTV transgenic mouse breast cancer model [abstract]. J Nucl Med 2003, 44:371P.

109. Shiue C, Shiue GG, Benard F, Visonneau S, Santoli D, Alavi AA: $\mathrm{N}$-(n-Benzylpiperidin-4-yl)-2-[18 $\mathrm{F}]$ fluorobenzamide: a potential ligand for PET imaging of breast cancer. Nucl Med Biol 2000, 27:763-767.

110. Shiue CY, Shiue GG, Zhang SX, Wilder S, Greenberg JH, Benard F, Wortman JA, Alavi AA: N-(N-benzylpiperidin-4-yl)-2-[18F]fluorobenzamide: a potential ligand for PET imaging of sigma receptors. Nucl Med Biol 1997, 24:671-676.

111. Bruskin A, Sivaev I, Persson M, Lundqvist H, Carlsson J, Sjoberg $\mathrm{S}$, Tolmachev $\mathrm{V}$ : Radiobromination of monoclonal antibody using potassium $\left.{ }^{76} \mathrm{Br}\right]$ (4 isothiocyanatobenzyl-ammonio)bromo-decahydro-closo-dodecaborate (Bromo-DABI). Nucl Med Biol 2004, 31:205-211.

112. Zheng QH, Fei X, Liu X, Wang JQ, Bin Sun H, Mock BH, Lee Stone K, Martinez TD, Miller KD, Sledge GW, et al:: Synthesis and preliminary biological evaluation of MMP inhibitor radiotracers [ ${ }^{11} \mathrm{C}$ ]methyl-halo-CGS $27023 \mathrm{~A}$ analogs, new potential PET breast cancer imaging agents. Nucl Med Biol 2002, 29: 761-770.

113. Reubi JC: Peptide receptors as molecular targets for cancer diagnosis and therapy. Endocr Rev 2003, 24:389-427. 